\title{
Genetic diversity in soybean seed quality under different storage conditions
}

\section{Diversidade genética para qualidade de sementes de soja em diferentes condições de armazenamento}

\author{
Daniele Piano Rosa ${ }^{1 *}$; Danúbia Aparecida Costa Nobre ${ }^{2}$; \\ Diego Santos Oliveira ${ }^{3}$; Francisco Charles dos Santos Silva ${ }^{1}$; \\ André Ricardo Gomes Bezerra ${ }^{1}$; Amilton Ferreira da Silva ${ }^{4}$; Tuneo Sediyama ${ }^{5}$
}

\begin{abstract}
This study aimed to assess the effect of genetic diversity on physiological quality of soybean seeds stored in cold chamber and under environmental conditions. Ten cultivars were assessed in a randomized factorial design $(2 \times 10)$. Factor 1 corresponded to two storage conditions and factor 2 to ten soybean cultivars, with four replications. The evaluated variables were total germination $(\mathrm{G} \%)$, first count of germination ( $\mathrm{F} \%$ ), percentage of abnormal seedlings (AS\%), germination speed index (GSI), water content (WC), electrical conductivity (EC), dry matter of seedlings (DMS) and length of seedlings (LS). Data underwent ANOVA, followed by Scott Knott test, as well as multivariate analysis of genetic diversity. The results showed a higher physiological quality for seeds under cold storage. Half of the cultivars (FPS Júpiter, FPS Urano, FPS Antares, FPS Netuno and CD 250) presented high germination rates and seed vigor, being thus indicated as high-standard materials for further breeding programs. Besides that, storage environment had influence on the clustering of soybean cultivars. Moreover, cultivars had genetic dissimilarity for almost all assessed traits as G\%, GSI, F\%, AS\%, EC, DMS and LS.
\end{abstract}

Key words: Dissimilarity. Germination. Glycine $\max ($ L.) Merrill. Vigor.

\section{Resumo}

Os objetivos desse estudo foram avaliar o desempenho e a diversidade genética de cultivares de soja quanto à qualidade fisiológica de sementes submetidas ao armazenamento em câmara fria e em condição ambiental. Foram utilizadas sementes de dez cultivares de soja; o experimento foi disposto em esquema fatorial (2x10), sendo o fator um: dois ambientes de armazenamento e o fator dois: dez cultivares de soja, com quatro repetições em delineamento inteiramente casualizado. Avaliou-se germinação, primeira contagem de germinação, porcentagem de plântulas anormais, índice de velocidade de germinação, teor de água, condutividade elétrica, matéria seca de plântula e comprimento de plântula. Os dados

\footnotetext{
${ }^{1}$ Discentes do Curso de Doutorado, Programa de Pós-Graduação em Fitotecnia, Departamento de Fitotecnia, Universidade Federal de Viçosa, UFV, Viçosa, MG, Brasil. E-mail: piano_dani@yahoo.com.br; fcsantossilva-ma@hotmail.com; andre_ricardogbi@, yahoo.com.br

2 Prof. Dr., Ciências Agrárias, Instituto Federal do Norte de Minas Gerais, IFNMG, Arinos, MG, Brasil. E-mail: danubia_nobre@ yahoo.com.br

3 Discente do Curso de Graduação em Agronomia, Bolsista de Iniciação Científica CNPq, Departamento de Fitotecnia, UFV, Viçosa, MG, Brasil. E-mail: diego.agro.ufv@gmail.com

${ }^{4}$ Prof. Dr., Departamento de Ciências Agrárias, Universidade Federal de São João Del-Rei, UFSJ, Campus Sete Lagoas, Sete Lagoas, MG, Brasil. E-mail: amiltonferreira@ufsj.edu.br

${ }^{5}$ Prof. PhD, Departamento de Fitotecnia, UFV, Viçosa, MG, Brasil. E-mail: tuneo@ufv.br

* Author for correspondence
} 
foram submetidos a análise de variância $(\mathrm{p}<0,05)$, teste Scott Knott e análises multivariadas para estudo da diversidade genética. Concluiu-se que a qualidade fisiológica de sementes foi superior no armazenamento em câmara fria em relação ao armazenamento em condição ambiental; os lotes das cultivares FPS Júpiter, FPS Urano, FPS Antares, FPS Netuno e CD 250 apresentaram alta geminação e vigor, sendo indicados como os materiais elites quanto à qualidade fisiológica para os programas de melhoramento; os ambientes de armazenamento influenciaram no agrupamento das cultivares de soja; houve dissimilaridade genética entre as cultivares para os caracteres porcentagem de germinação, índice de velocidade de germinação, primeira contagem do teste de germinação, número de plântulas anormais, condutividade elétrica, massa de matéria seca de plântulas e comprimento de plântula.

Palavras-chave: Dissimilaridade. Germinação. Glycine max (L.) Merrill. Vigor.

\section{Introduction}

Seed physiological quality is important for soybean commercial productivity, since it is directly related to fast emergence and germination uniformity, providing vigorous seedlings that shall ensure good crop performance. Seeds with great physiological potential are able to mobilize energy from cotyledon reserves to the embryo efficiently. This feature speeds up germination process in field conditions and, as a result, seedlings are considered of superior quality since final yield and product quality are increased (AZEVEDO et al., 2003; MARCOS FILHO, 2005).

According to literature reports, several factors interfere with seed quality. Among them, storage plays an important role in seed quality; this procedure is used to maintain seed vigor and germinating power for a long term (GOLDFARB; QUEIROGA, 2013). Zucareli et al. (2015) reported lower physiological quality in seeds under room conditions compared to those under dry chamber storage. These authors stated that seed deterioration is natural process, however, when seeds are exposed to temperature and humidity changes, they might lose vigor faster. Likewise, Smaniotto et al. (2014) asserted the direct influence of time, temperature and storage conditions on soybean seed quality; they reported that when stored for 180 days under high temperature $\left(27^{\circ} \mathrm{C}\right)$, germination rates decreased drastically, even for seeds with low water content.

Marcos Filho (2001) highlighted environment temperature and relative humidity as major factors acting on seed quality maintenance during storage.
Seeds stored under high temperature and water content present increased respiratory rates, which aggravate deterioration expediting consumption of reserves, generating physiological wear and tear that will decrease germination rates and seed vigor (SILVA, 2008; ULLMANN et al., 2015). Similarly, Alencar et al. (2008) reported increasing soybean seed deterioration by combinations of high temperature and high water levels.

Another factor influencing the physiological quality of seeds is genetic diversity, being of utmost importance during pre-breeding, which is a promising alternative to link genetic resources and breeding programs. The main goal of genetic diversity studies is to identify suitable parents to increase segregation resulting in transgressive hybrids (CRUZ et al., 2011), therefore, contributing to select soybean plants with superior seed physiological quality.

Breeders use multivariate techniques to evaluate genetic diversity. To this end, measuring dissimilarity is necessary to build a matrix of distance between pairs of individuals and then group them according to their dissimilarity. There are several clustering methods available; however, the choice for one of them should be based on the researcher's knowledge about the target crop and on the desired grouping pattern.

Mengarda et al. (2015), testing contrasting parental genotypes of papaya (Carica papaya L.), identified a few with higher performance for seed quality. Similarly, Pessoa et al. (2015) found dissimilarity regarding physiologic quality 
in $\mathrm{F}_{2}$ population of pepper. These authors also stated that identifying contrasting genotypes, as well as the better understanding of phenotypic variations among individuals within a population are crucial in the continued process of selection in breeding programs. Furthermore, Nerling et al. (2013) evaluated native genotypes, open pollinated varieties and commercial corn hybrids and detected heterosis among them; based on that, they observed promising crosses for production of seeds with higher physiological quality.

Even though Carvalho et al. (2014) reported that current researches aim to select soybean genotypes whose seeds owns greater storage capacity, few reports are found regarding the effect of genetic diversity on seed physiological quality for soybean. Therefore, further studies on this topic are required to improve scientific knowledge on such field, since similar studies would contribute to identification and selection of new parents in breeding programs.

Thus, our goals were to evaluate the cultivars performance and the effect of genetic diversity on physiological quality of soybean seeds under different storage environments.

\section{Material and Methods}

Seeds belonging to ten soybean cultivars (FPS Júpiter, FPS Urano, FPS Antares, FPS Netuno, BRS Tordilha, A 6411, NS 5909, CD 2585, CD 219 and CD 250) were sown and grown under the same environmental conditions, being harvested in 2013 from a production field in Erechim city, Rio Grande do Sul state, Brazil. The area is located at the geographical coordinates of $27^{\circ} 37^{\prime} 50^{\prime}$ ' South latitude and $52^{\circ} 14$ ' 11 " West longitude, at 753 altitude meters.

Harvested seeds were packed in polyethylene bags. Part of them were stored in cold chamber $(10 \pm$ $1.5^{\circ} \mathrm{C}$ and $\left.\pm 61 \% \mathrm{RH}\right)$. Another part were left under room conditions $\left( \pm 26^{\circ} \mathrm{C}\right.$ and $\left.\pm 50 \% \mathrm{RH}\right)$ in Viçosa, Minas Gerais state, Brazil; during storage, a digital recorder monitored environment temperature. Evaluations of seed quality were carried out after eight months of storage for both environments.

Moisture content of seeds was determined by the standard oven method, at $105 \pm 3^{\circ} \mathrm{C}$ for 24 hours, with four replications of 25 seeds for each cultivar, as prescribed by the Brazilian Rules for Seed Analysis (BRASIL, 2009).

Germination test was conducted with four replications of 50 seeds (G\%). After storage, seeds were placed on two germination papers (Germitest), pre-soaked with 2.5 times distilled water per paper dry weight. Then, they were placed in a B.O.D. type germination chamber at constant temperature of 25 ${ }^{\circ} \mathrm{C}$ and photoperiod of 12 hours. Evaluations were performed on the fifth and the eighth day, after test installation, by registering normal seedlings, which were characterized by intact, well-developed, and proportional essential structures such as shoot and roots (BRASIL, 2009). At the end, the number of abnormal seedlings was recorded and results expressed as percentage (AS\%). Herewith, the first count of germination ( $\mathrm{FC} \%$ ) was conducted by counting the number of normal seedlings on the fifth day (BRASIL, 2009).

Additionally, analysis of germination speed index (GSI) was conducted at the same moment with the germination test, considering daily counts of the radicle protrusion from the seed coat during the eight-day trial; GSI was estimated through formula proposed by Maguire (1962).

After eight days of evaluation, normal seedlings of each replication was measured, with the aid of a millimeter ruler, for the average length, in each cultivar. Lately, seedlings were weighed on a precision scale and placed into a forced-air circulation oven at $65{ }^{\circ} \mathrm{C}$, until constant weight, thereby obtaining their dry matter weights.

An electrical conductivity test was performed in four replicates of 50 seeds. Seeds were soaked in $75 \mathrm{~mL}$ deionized water $\left(<2.0 \mu \mathrm{S} \mathrm{cm} \mathrm{cm}^{-1}\right)$ and left in B.O.D. chambers at a constant temperature of 25 
${ }^{\circ} \mathrm{C}$ for 24 hours. Measures of electrical conductivity were taken by digital conductivity meter (Digimed DM-32) from solutions. Each record was divided by each sample weight and results were expressed in $\mu \mathrm{S} \mathrm{cm} \mathrm{g}^{-1} \mathrm{~g}^{-1}$.

Experimental design was completely randomized with four replications, arranged in a factorial scheme $(2 \times 10)$. Factor 1 consisted of two storage environments, as the factor 2 represented ten soybean cultivars. Data were submitted to analysis of variance, and the averages were compared by the Scott Knott test, both at 5\% probability $(\mathrm{p}<0.05)$.

Genetic diversity study was done using multivariate techniques, and conclusions were based on joint analysis and interpretation of canonical variables, two-dimensional graphical representation and clustering methods as the Unweighted Pair Group Method with Arithmetic Means (UPGMA) and Tocher.

Dissimilarity matrixes between pairs of cultivars were estimated by means of the Generalized Mahalanobis Distance $\left(\mathrm{D}^{2}\right)$, wherein: $D_{\mathbb{i}^{\prime}}^{2}=\delta^{\psi^{-1}} \delta$ and $D_{\ddot{u}^{\prime}}^{2}=$ Mahalanobis distance between $\mathrm{i}$ and i'genotypes; $\psi=$ residual covariance and variance matrices; $\delta^{\prime}=\left[\begin{array}{lll}\mathrm{d} 1 & \mathrm{~d} 2 \ldots \mathrm{dv}\end{array}\right]$, being $d_{j}=Y_{i j}-Y_{i^{\prime} j}$ and, $Y_{i j}=$ average of the $\mathrm{i}^{\text {th }}$ genotype regarding to the $\mathrm{j}^{{ }^{\text {th }}}$ variable.

The analysis of canonical variables and twodimensional graphical representation were performed according to method described by Cruz et al. (2011).

UPGMA clustering was made by means of dendrogram, which was established by individual similarity and the distance between a cultivar and a group formed by $\mathrm{i}$ and $\mathrm{j}$ cultivars, which was calculated by the following formula: $d_{(i j) k}=\operatorname{average}\left(d_{i k} ; d_{j k}\right)=\frac{d_{i k}+d_{j k}}{2}$.
In Tocher method, dissimilarity matrix was used to form the first pair of similar genotypes. The inclusion of a new cultivar into a group was made by comparing the average of increased distance within the group and the maximum allowable level (" $\theta$ )" of dissimilarity, which may be the highest value in the set of shorter distances for each individual. Thus, if $\frac{d_{(g r u p o) k}}{=\leq \theta}$, the $\mathrm{k}$ individual will be included to the ${ }_{\text {group; }}^{n}$ and if $\frac{d_{(\text {grupo }) k}}{n}=>\theta$, the $\mathrm{k}$ individual will not be included to the group; $n$ is the number of individuals integrating the initial group. Statistical analyses were processed using Genes software a computer application in Genetics and Statistics (CRUZ, 2013).

\section{Results and Discussion}

\section{Performance of cultivars}

The ANOVA showed significant interaction between cultivar and environment $(\mathrm{CxE})$ for all variables, except for WC which only differed significantly for E. Differently, EC was significant for both factors. Therefore, exploitation of the effects from $\mathrm{CxE}$ interactions could be made, identifying then genotypes of higher seed physiological quality under both storage environments.

Table 1 shows the coefficient of variation (CV) range which varied from $4.15 \%$ to $28.60 \%$ for DMS and AS, respectively. Other authors observed similar $\mathrm{CV}$ values of $7.46 \%$ for papaya seeds (CARDOSO et al., 2009), from $11.95 \%$ to $22.77 \%$ for soybean (VANZOLINI et al., 2007) and of $9.07 \%$ for Mimosa caesalpiniaefolia Benth (ALVES et al., 2002). These authors also reported CV of $23.95 \%$ for $\mathrm{AS} \%$. Thus, we can state that $\mathrm{CV}$ values found here were close to those reported in literature for the same traits. 
Table 1. Summary of variance analysis of water content (WC, g), germination speed index (GSI), electrical conductivity $\left(\mathrm{EC}, \mu \mathrm{S} \mathrm{cm}^{-1} \mathrm{~g}^{-1}\right.$ ), first count of germination ( $\mathrm{FC}, \%$ ), number of abnormal seedlings (AS, \%), germination percentage (GP, \%), dry matter of seedlings (DMS, g) and length of seedlings (LS, cm) for ten soybean cultivars after eight months of storage in cold chamber and under environmental conditions.

\begin{tabular}{|c|c|c|c|c|c|c|c|c|c|}
\hline \multirow{2}{*}{ Sources } & \multicolumn{9}{|c|}{ Mean Squares } \\
\hline & GL & $\mathrm{WC}$ & & GSI & & $\overline{\mathrm{EC}}$ & & $\mathrm{FC}$ & \\
\hline Cultivars (C) & 9 & 1.407 & ns & 148.165 & ** & 6828.042 & $* *$ & 2274.31 & ** \\
\hline Environments (E) & 1 & 21.590 & ${ }^{* *}$ & 1473.529 & ** & 3052.179 & ** & 21839.4 & ** \\
\hline Cult $x$ Env (CxE) & 9 & 1.245 & ns & 19.002 & ** & 117.072 & ns & 179.352 & ** \\
\hline Residual & 60 & 0.794 & & 2.145 & & 219.100 & & 34.2402 & \\
\hline Mean & - & 11.172 & & 25.650 & & 106.0235 & & 56.9275 & \\
\hline CV $(\%)$ & - & 7.98 & & 5.71 & & 13.96 & & 10.28 & \\
\hline Sources & GL & AS & & GP & & DMS & & LS & \\
\hline Cultivars (C) & 9 & 367.477 & ns & 1751.244 & ns & 0.342 & ns & 260.530 & ** \\
\hline Environments (E) & 1 & 1101.128 & ** & 5248.800 & ** & 0.623 & ** & 299.228 & ** \\
\hline Cult x Env (CxE) & 9 & 119.567 & ** & 640.022 & ** & 0.116 & ** & 21.749 & ** \\
\hline Residual & 60 & 7.290 & & 30.867 & & 0.018 & & 4.954 & \\
\hline Mean & - & 9.440 & & 80.150 & & 3.2195 & & 20.819 & \\
\hline CV $(\%)$ & - & 28.60 & & 6.93 & & 4.15 & & 10.69 & \\
\hline
\end{tabular}

${ }^{* *}$ Significant at $5 \%$ probability by the $\mathrm{F}$ test. ${ }^{\mathrm{ns}}$ Non-significant. $\mathrm{CV}$ : coefficient of variation.

As mentioned above, WC had no significant difference between cold chamber $(10.65 \%)$ and environmental condition (11.69\%). It can be explained by similarities in both environments, such as little variation in humidity from environmental conditions (69\% to $82.6 \%)$ to cold room $(65 \%)$ throughout the eight months storage. Regrettably, statistical differences of seed moisture content between environments could not be detected (Figure 1).

By comparing cultivar performances in each storage environment, we observed the highest averages of $\mathrm{G} \%$ in cold chamber for FPS Júpiter, FPS Antares, FPS Urano, FPS Netuno, BRS Tordilha and CD 250. On the other hand, under environmental condition, the highest averages were registered for FPS Urano, FPS Netuno and CD 250 (Table 2). Based on this, we may highlight these cultivars as superior regarding physiological and genetic quality, since genetics has influence on storage potential, being related to seed vigor (CARVALHO; NAKAGAWA, 2012). Likewise,
Carvalho and Nakagawa (2000) reported that seed viability depends on genetics and storage conditions. This is because once seed metabolism is activated, and no germination occurs, an increasing deterioration may cause the total loss of viability.

With respect to G\%, FPS Antares, FPS Urano, FPS Netuno and CD 250 cultivars showed no significant differences between cold storage and environmental condition, keeping rates above $80 \%$ for both environments, while FPS Urano and FPS Netuno rates were greater than 90\% (Table 2). Such result could be an indication of potential to withstand long periods of storage in both environments. However, this feature alone is not able to define vigor of a seed lot; other variables such as FC and GSI are of utmost importance to state this characteristic. This way, these variables together may confirm that despite the high G\% averages of these cultivars, in both environments, seed vigor of the lots can be higher when stored in cold chambers. 
Figure 1. Mean data of air temperature $\left({ }^{\circ} \mathrm{C}\right)$ and relative humidity $(\%)$ in Viçosa - MG (Brazil) from November 2013 to June 2014. Values adapted from meteorological data provided by the Main Climatological Station of Viçosa (UFV, 2016).

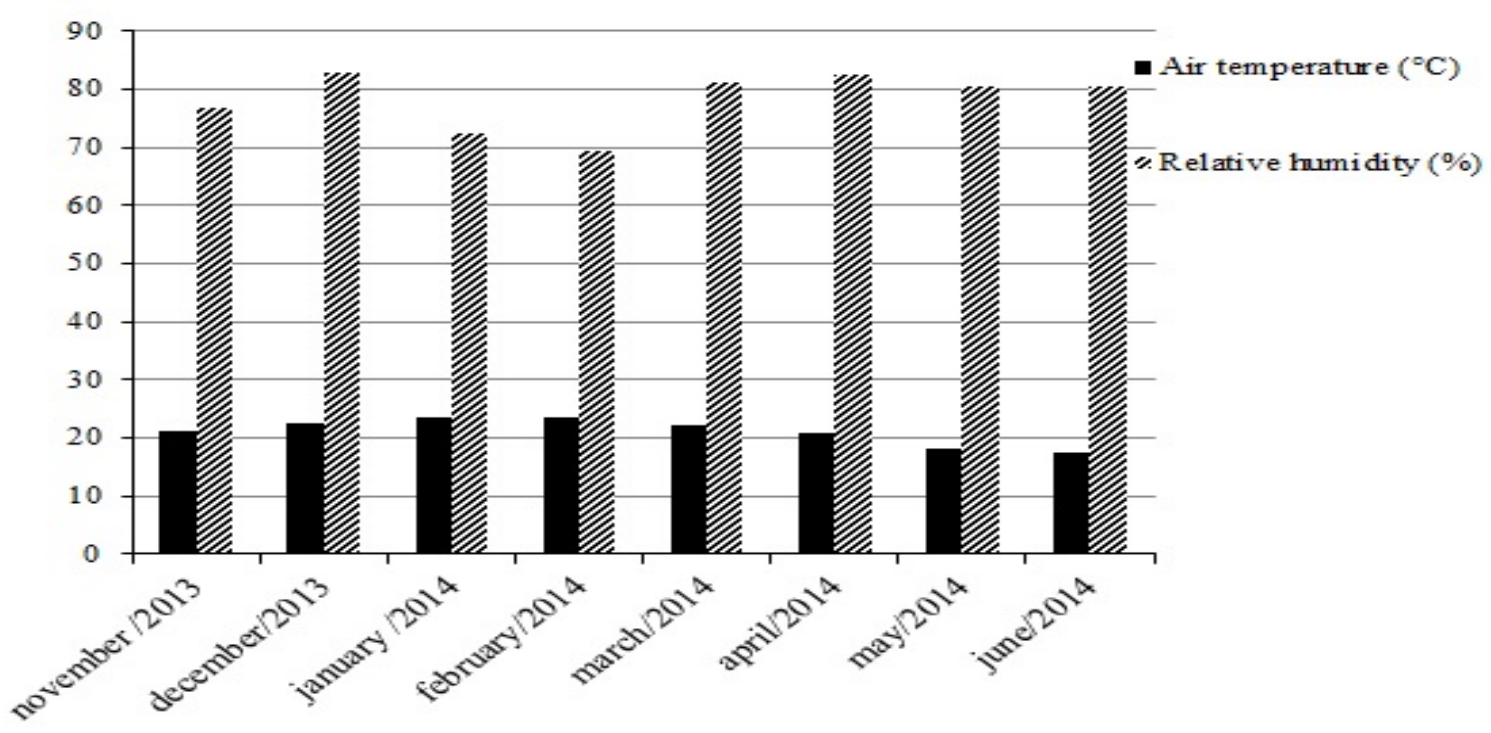

Storage at low temperatures tends to preserve seed physiological quality. According to Black et al. (2006), a drop of $6{ }^{\circ} \mathrm{C}$ in temperature could double lifetime of a seed lot. In adition, Carvalho et al. (2014) assessed six soybean cultivars stored in different environments and observed that, after eight months, G\% was higher for seeds kept in cold chamber than those in warehouse for all evaluated cultivars. These authors also noted a high efficiency to maintain viability in seeds stored in cold chamber, especially after the first six months.

As for GSI, seeds stored in cold had higher performances. Analyzing storage environment, cold chamber promoted higher GSI values for FPS Júpiter, FPS Antares, FPS Urano, FPS Netuno, CD 250 and NS 5909, while lower values were found for A 6411, BRS Tordilha, CD 2585 e CD 219, being their averages grouped in a separate group.

As a result, we can state that genetic factors strongly influence the effects of different seed varieties stored in the same location. Therefore, the selection of high-quality soybean cultivars, tolerant to long term storage under cold conditions, becomes possible. Similarly, Santos et al. (2012) reported different emergency speed in field conditions due to genetic variability among soybean genotypes. Furthermore, Nerling et al. (2013) reported different G\% and GSI derived from genetic variability among intervarietal crosses of corn. The same authors also claimed fast senescence as an efficient trait to discriminate the genetic potential of materials.

Both FPS Antares and CD 250 showed the best performances on GSIfor storage underenvironmental conditions, without statistical difference from each other. Since these cultivars were superior both in cold as under environmental conditionss, for GSI, FC and G\%, they can be classified as seed lots of high vigor and, therefore, being considered high-standard materials for selection in breeding programs. These results corroborate the ones of Martins et al. (2016) who claimed certain soybean seed traits as indicative of significant contributions brought by genetic improvement in physiological quality. 
Table 2. Means of germination percentage (GP, \%), germination speed index (GSI), first count of germination (FC, $\%$ ), number of abnormal seedlings (AS\%), dry matter of seedlings (DMS, g) and length of seedlings (LS, cm) for ten soybean cultivars after eight months of storage in cold chamber and under environmental conditions.

\begin{tabular}{|c|c|c|c|c|c|c|c|c|c|c|c|c|c|c|c|c|c|}
\hline \multirow{3}{*}{$\begin{array}{l}\text { Cultivars } \\
\text { A } 6411\end{array}$} & \multicolumn{5}{|c|}{ GP } & \multicolumn{6}{|c|}{ GSI } & \multicolumn{6}{|c|}{$\mathrm{FC}$} \\
\hline & \multicolumn{3}{|c|}{$\begin{array}{c}\text { Cold } \\
\text { chamber }\end{array}$} & \multicolumn{2}{|c|}{ Environment } & \multicolumn{3}{|c|}{$\begin{array}{c}\text { Cold } \\
\text { chamber }\end{array}$} & \multicolumn{3}{|c|}{ Environment } & \multicolumn{3}{|c|}{$\begin{array}{c}\text { Cold } \\
\text { chamber }\end{array}$} & \multicolumn{3}{|c|}{ Environment } \\
\hline & 80.00 & A & $\mathrm{b}$ & 17.50 & $\mathrm{~B} \mathrm{e}$ & 25.38 & $\mathrm{~A}$ & $\mathrm{~b}$ & 9.59 & $\mathrm{~B}$ & $\mathrm{e}$ & 51.00 & A & & 1.55 & B & $\mathrm{d}$ \\
\hline FPS Júpiter & 97.00 & A & $\mathrm{a}$ & 84.50 & $\mathrm{~B} b$ & 31.77 & A & $\mathrm{a}$ & 23.86 & $\mathrm{~B}$ & $\mathrm{~b}$ & 90.00 & A & & 52.00 & B & $\mathrm{a}$ \\
\hline FPS Antares & 90.00 & A & $\mathrm{a}$ & 83.00 & $\mathrm{~A} \mathrm{~b}$ & 33.88 & A & $\mathrm{a}$ & 27.45 & $\mathrm{~B}$ & $\mathrm{a}$ & 84.00 & A & & 62.00 & B & $\mathrm{a}$ \\
\hline FPS Urano & 94.00 & A & $\mathrm{a}$ & 90.50 & $\mathrm{~A}$ a & 32.84 & A & $\mathrm{a}$ & 22.85 & $\mathrm{~B}$ & $\mathrm{~b}$ & 85.50 & A & a & 54.50 & B & $\mathrm{a}$ \\
\hline FPS Netuno & 94.50 & A & $\mathrm{a}$ & 93.00 & $\mathrm{~A}$ a & 33.08 & $\mathrm{~A}$ & $\mathrm{a}$ & 24.33 & $\mathrm{~B}$ & $\mathrm{~b}$ & 85.50 & A & $\mathrm{a}$ & 55.50 & B & $\mathrm{a}$ \\
\hline BRS Tordilha & 94.50 & A & $\mathrm{a}$ & 80.50 & $\mathrm{~B} b$ & 26.26 & $\mathrm{~A}$ & $\mathrm{~b}$ & 20.94 & $\mathrm{~B}$ & $\mathrm{c}$ & 71.50 & A & b & 41.50 & B & $\mathrm{b}$ \\
\hline $\mathrm{CD} 2$ & 91.50 & A & $\mathrm{a}$ & 88.00 & $\mathrm{~A}$ a & 33.50 & $\mathrm{~A}$ & $\mathrm{a}$ & 26.47 & $\mathrm{~B}$ & $\mathrm{a}$ & 82.50 & A & a & 60.50 & B & $\mathrm{a}$ \\
\hline NS 5909 & 85.00 & A & $\mathrm{b}$ & 67.00 & $\mathrm{~B} \mathrm{c}$ & 32.42 & $\mathrm{~A}$ & $\mathrm{a}$ & 21.58 & $\mathrm{~B}$ & $\mathrm{c}$ & 73.50 & A & & 25.50 & $\mathrm{~B}$ & $\mathrm{c}$ \\
\hline $\mathrm{CD}$ & 80.00 & $\mathrm{~A}$ & $\mathrm{~b}$ & 66.00 & $\mathrm{~B} \mathrm{c}$ & 24.70 & $\mathrm{~A}$ & $\mathrm{~b}$ & 18.96 & $\mathrm{~B}$ & $\mathrm{~d}$ & 55.00 & A & $\mathrm{c}$ & 26.50 & $\mathrm{~B}$ & $\mathrm{c}$ \\
\hline & 6.00 & $\mathrm{~A}$ & $\mathrm{~b}$ & 50.50 & $\mathrm{~B} \mathrm{~d}$ & 25.59 & $\mathrm{~A}$ & $\mathrm{~b}$ & 17.57 & $\mathrm{~B}$ & $\mathrm{~d}$ & 56.00 & A & 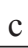 & 24.50 & $\mathrm{~B}$ & $\mathrm{c}$ \\
\hline \multirow[b]{2}{*}{ Cultivars } & \multicolumn{5}{|c|}{ AS } & \multicolumn{6}{|c|}{ DMS } & \multicolumn{6}{|c|}{ LS } \\
\hline & \multicolumn{3}{|c|}{$\begin{array}{c}\text { Cold } \\
\text { chamber }\end{array}$} & \multicolumn{2}{|c|}{ Environment } & \multicolumn{3}{|c|}{$\begin{array}{c}\text { Cold } \\
\text { chamber }\end{array}$} & \multicolumn{3}{|c|}{ Environment } & \multicolumn{3}{|c|}{$\begin{array}{c}\text { Cold } \\
\text { chamber }\end{array}$} & \multicolumn{3}{|c|}{ Environment } \\
\hline A 641 & 9.75 & $\mathrm{~B}$ & $\mathrm{a}$ & 36.50 & A a & 3.42 & $\mathrm{~A}$ & $\mathrm{~b}$ & 2.70 & $\mathrm{~B}$ & $\mathrm{~d}$ & 11.57 & A & & 3.40 & B & d \\
\hline FPS Júpiter & 1.53 & $\mathrm{~B}$ & $\mathrm{~b}$ & 7.50 & A d & 3.65 & A & $\mathrm{a}$ & 3.37 & $\mathrm{~B}$ & $\mathrm{a}$ & 26.34 & A & & 22.40 & B & $\mathrm{a}$ \\
\hline FPS Antares & 4.75 & A & $\mathrm{b}$ & 8.50 & A d & 3.36 & $\mathrm{~A}$ & $\mathrm{c}$ & 3.31 & A & $\mathfrak{a}$ & 23.21 & A & a & 23.50 & A & $\mathrm{a}$ \\
\hline FPS Urano & 3.00 & $\mathrm{~A}$ & $\mathrm{~b}$ & 4.50 & $\mathrm{~A}$ e & 3.70 & $\mathrm{~A}$ & $\mathrm{a}$ & 3.46 & $\mathrm{~B}$ & $\mathrm{a}$ & 25.74 & $\mathrm{~A}$ & $\mathrm{a}$ & 25.04 & A & $\mathrm{a}$ \\
\hline FPS Netuno & 2.78 & A & $\mathrm{b}$ & 3.25 & $\mathrm{~A}$ e & 3.32 & A & $\mathrm{c}$ & 3.18 & A & $\mathrm{b}$ & 24.23 & A & $\mathrm{a}$ & 20.44 & B & $\mathrm{b}$ \\
\hline BRS Tordilha & 2.75 & $\mathrm{~B}$ & $\mathrm{~b}$ & 9.00 & A d & 3.27 & A & $\mathrm{c}$ & 3.10 & A & $\mathrm{b}$ & 24.85 & A & $\mathrm{a}$ & 20.56 & B & $\mathrm{b}$ \\
\hline CD 250 & 4.25 & $\mathrm{~A}$ & $\mathrm{~b}$ & 5.75 & $\mathrm{~A}$ e & 3.24 & $\mathrm{~A}$ & $\mathrm{c}$ & 3.18 & A & $\mathrm{b}$ & 26.63 & A & $\mathrm{a}$ & 24.81 & A & $\mathrm{a}$ \\
\hline NS 5909 & 7.00 & $\mathrm{~B}$ & $\mathrm{a}$ & 16.00 & $\mathrm{~A} \mathrm{c}$ & 3.02 & $\mathrm{~B}$ & d & 3.26 & A & $\mathrm{b}$ & 24.84 & $\mathrm{~A}$ & $\mathrm{a}$ & 20.93 & B & $\mathrm{b}$ \\
\hline CD 2585 & 10.00 & $\mathrm{~B}$ & $\mathrm{a}$ & 16.50 & $\mathrm{~A} \mathrm{c}$ & 3.00 & A & d & 2.90 & A & $\mathrm{c}$ & 20.37 & A & D & 18.49 & $\mathrm{~A}$ & $\mathrm{~b}$ \\
\hline CD 219 & 11.50 & $\mathrm{~B}$ & $\mathrm{a}$ & 24.00 & $\mathrm{~A} \mathrm{~b}$ & 3.11 & $\mathrm{~A}$ & d & 2.88 & $\mathrm{~B}$ & $\mathrm{c}$ & 19.79 & $\mathrm{~A}$ & 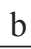 & 9.31 & & \\
\hline
\end{tabular}

Means followed by the same capital letters horizontally and lower letter vertically do not differ from each other significantly by the Scott Knott's test at 5\% probability.

Newly, all cultivars under study showed higher averages for FC when seeds were stored in cold chamber compared those under environmental conditions. Likewise, Smaniotto et al. (2014) also observed reduction in $\mathrm{FC} \%$ for soybean seeds stored at $27{ }^{\circ} \mathrm{C}$ against those stored at $20{ }^{\circ} \mathrm{C}$. According to Silva (2008), low temperatures tend to preserve seed quality because of proportional increases in respiratory rates and water content of the seeds, causing further deterioration.

When comparing cultivars within each storage environment, we found different performances regarding FC. The cultivars FPS Júpiter, FPS Antares, FPS Netuno, FPS Urano and CD 250 clustered into a group with the highest averages in cold storage. High performance genotypes per se have potential for breeding when combined with a high magnitude of genetic dissimilarity. Conversely, A 6411, CD 2585 and CD 219 had the lowest averages, being statistically different from the others. Under environmental conditions, the cultivars with higher performance were the same as under cold room; however, only A 6411 exhibited the lowest average, being statistically different from the others.

FPS Júpiter, FPS Antares, FPS Urano, FPS Netuno and CD 250 presented the highest averages for FC in both environments. It is worth noting that these cultivars, when stored in cold chamber, by occasion of FC, they had already reached the 
minimum $\mathrm{G} \%$ of $80 \%$, which is recommended by the National System of Seeds and Seedlings for certified soybean seeds, evidencing their high vigor.

For DMS, there was no difference between the environments for FPS Antares, FPS Netuno, BRS Tordilha, CD 250 and CD 2585. The greatest average was observed for seedlings originated from seeds stored in cold chamber, except for NS 5909 (Table 2 ). Under cold storage, FPS Júpiter and FPS Urano achieved the highest averages; yet for those under environmental condition, FPS Júpiter, FPS Antares and FPS Urano showed no difference at a 5\% probability (Table 2). Höfs et al. (2004), evaluating rice seeds, reported that plants from seeds with high physiological quality had greater dry matter weights. Another important point corroborating this fact is that similar performance was observed between FPS Júpiter and FPS Urano cultivars under cold storage, and among FPS Júpiter, FPS Antares and FPS Urano cultivars under environmental condition. By contrast, despite having a low physiological quality, A 6411 showed high DMS in cold chamber and low under environmental conditions; it means that even being of low vigor and stored at low temperature, this cultivar maintained for longer time its ability to form biomass and translocate assimilates. This result denotes that low temperatures contribute to the genetic potential of this cultivar, being expressed in terms of dry matter accumulation. However, the same was not observed for the other cultivars with low physiological quality, e.g. CD 2585 and CD 219 , as even under cold chamber conditions they were not able to accumulate high values of biomass.

Furthermore, LS was an efficient variable to separate cultivars by vigor levels. Comparing both storage environments, this variable was favored by cold, where the highest averages were found, except for FPS Antares, FPS Urano, CD 250 and CD 2585, which did not differ from each other (Table 2). For cultivars left in cold storage, higher averages were registered for FPS Júpiter, FPS Antares, FPS Urano, FPS Netuno, BRS Tordilha, CD 250, NS 5909 and CD 2585, being thus allocated into the same group.
Under environmental condition, FPS Júpiter, FPS Antares, FPS Urano and CD 250 presented the highest averages without differing from each other, at a 5\% probability; whereas A 6411 expressed the lowest average for length, therefore, forming a single group. These results point out that length of seedlings may vary with storage conditions and with cultivar genetic variability, which expresses the potential for this character. Differently, the same cannot be applied to lettuce seeds, Franzin et al. (2004) showed that length of seedlings had no significant differences, disabling its classification in lots by seed vigor.

Seed vigor testing based on FC, GSI and LS provided information similar to that furnished by the germination test, suggesting high sensibility of these tests to segregation of cultivars at different quality levels. Given that seed quality is the main goal in production process and, bearing in mind germination and seedling emergence, high vigor level is required to achieve a fast and uniform emergence, so plants can start photosynthesis earlier, what would favor shoot and root growth (KRZYZANOWSKI; FRANÇA NETO, 1999; VASCONCELOS et al., 2009).

Delouche and Baskin (1973) met the same conclusions by saying it is common that seed lots with similar G\% may perform varyingly in storage or in field. According to them, this is because the first changes in biochemical deterioration occur prior to detections of germination capacity decreases. Therefore, vigor test is useful to control seed quality.

In this study, there was no significant difference between the averages in cold chamber and under environmental conditions for EC. However, based on cultivars, it is noteworthy highlighting that cultivars with high vigor level had the lower averages; oppositely, A6411 showed low vigor and high averages for EC (Table 3). Vieira et al. (2002) also observed effects of genetic variability on EC, among six soybean cultivars in two growing seasons, thus corroborating the results of this research. 
Table 3. Means of electrical conductivity (EC) evaluated in ten soybean cultivars.

\begin{tabular}{lc}
\hline Cultivars & Electrical conductivity $\left(\mu \mathrm{S} \mathrm{cm}^{-1} \mathrm{~g}^{-1}\right)$ \\
\hline A 6411 & $172.36 \mathrm{a}$ \\
CD 2585 & $141.64 \mathrm{~b}$ \\
NS 5909 & $107.28 \mathrm{c}$ \\
BRS Tordilha & $106.19 \mathrm{c}$ \\
CD 219 & $95.91 \mathrm{c}$ \\
FPS Netuno & $95.29 \mathrm{c}$ \\
FPS Urano & $93.54 \mathrm{c}$ \\
FPS Júpiter & $83.62 \mathrm{c}$ \\
FPS Antares & $82.63 \mathrm{c}$ \\
CD 250 & $81.79 \mathrm{c}$ \\
\hline
\end{tabular}

Means followed by the same letters do not differ from each other significantly by the Scott Knott's test at 5\% probability.

Storage environment had no effect on FPS Antares, FPS Urano, FPS Netuno and CD 250 regarding AS\%. However, for the other cultivars, cold storage showed lower averages for this variable. The cultivars FPS Júpiter, FPS Antares, FPS Urano, FPS Netuno, BRS Tordilha and CD 250 were allocated in the same group, presenting the best averages in cold chamber. As for the environment condition, FPS Urano, FPS Netuno and CD 250 constituted the group with the best averages, followed by another group comprising FPS Júpiter, FPS Antares and BRS Tordilha. Once again, these achievements confirm the importance of high vigor seeds to decrease the number of abnormal seedlings. It is known that increasing $\mathrm{AS} \%$ is linked to a raise on physiological quality deterioration during the storage. For Roberts (1972), this process cause harm to membranes, enzymes, proteins and nucleic acids, and as storage time increases, degeneration gives rise to membrane disruption and leads to the death.

Breeding programs can be more efficient in evaluating plant cultivars by quality of seeds, selecting then superior plants. By assuming that storage environments have an effect on cultivar performance, caused by an interaction between genotype and environment, we carried out individual analysis of each environment because clustering can be affected by the environment in multivariate analyzes. So the discussion of the clustering results was addressed, sequentially, in cold storage and environmental condition.

\section{Genetic diversity in cold chamber}

Genetic distances between pairs of cultivars were estimated based on the dissimilarity matrix. The lowest value was observed for the pair FPS Júpiter and FPS Urano $\left(D_{i^{\prime}}^{2}=2.24\right)$; therefore, these are individuals with less dissimilarity for physiological quality of seeds. Parents with small genetic distances between them tend to share several genes or alleles in common and, thus, their crossing generates little complementarity and low vigor, given the low level of allelic heterozygosity (GHADERI et al., 1984; CRUZ et al., 2011).

On the other side, the longest genetic distance was found for the pair NS 5909 and A6411 $\left(D_{\mathbb{u}^{\prime}}^{2}=\right.$ 864.55). Pairwise distant values indicate genetic diversity and variability between the materials (RIGON et al., 2012; VILLELA, 2013). Genetic divergence between parents provides higher expression of heterosis in the segregating population, which is essential for selecting superior individuals (FALCONER, 1981). According to Ghaderi et al. (1984), long genetic distances between two parents increase the likelihood of a large number of distinct loci, from which dominance effects are evident, contributing to higher manifestation of heterosis.

The first two canonical variables explained $95.80 \%$ and $93.71 \%$ of the total variation in cold chamber and environmental condition, respectively. Thus, the similarity among cultivars could be studied 
in a two-dimensional space (Table 4). According to Cruz et al. (2011), graphical analysis should be considered only when a few canonical variables summarize more than $80 \%$ of the total variation.

For cold chamber, either the analysis of canonical variables by two-dimensional graphical representation as UPGMA and Tocher clustering showed similar results, confirming thus an existing genetic dissimilarity among the cultivars under this condition (Figures 2A and 3A; Tables 4 and $5)$. The joint use of clustering methods and graph scattering has been the best suitable alternative in genetic diversity studies. It may occurs because the clustering methods involving dissimilarity matrices with high orders can cause information loss on the degree of dissimilarity of individuals within of a same group. By contrast, only graph scattering makes the clustering of individuals subjective through a visual analysis (CRUZ et al., 2011).

Table 4. Variances, percent variances and accumulated variances in percentage for the canonical variables in ten soybean cultivars stored in cold chamber and under environmental conditions.

\begin{tabular}{lrrrrrrrr}
\hline Canonical & \multicolumn{3}{c}{ Cold chamber } & & \multicolumn{3}{c}{ Environmental condition } \\
\cline { 2 - 4 } \cline { 6 - 8 } variables & \multicolumn{1}{c}{ Root } & Root $(\%)$ & \% accumulated & & Root & Root $(\%)$ & \% accumulated \\
\hline CV 1 & 74.75 & 78.48 & 78.48 & & 58.91 & 88.28 & 88.28 \\
CV 2 & 16.50 & 17.32 & 95.80 & & 3.62 & 5.43 & 93.71 \\
CV 3 & 1.72 & 1.81 & 97.60 & & 2.13 & 3.19 & 96.89 \\
CV 4 & 1.11 & 1.16 & 98.76 & & 1.06 & 1.59 & 98.48 \\
CV 5 & 1.01 & 1.06 & 99.82 & & 0.67 & 1.00 & 99.48 \\
CV 6 & 0.12 & 0.12 & 99.95 & & 0.21 & 0.32 & 99.80 \\
CV 7 & 0.03 & 0.03 & 99.98 & & 0.13 & 0.20 & 99.99 \\
CV 8 & 0.02 & 0.02 & 100.00 & & 0.01 & 0.01 & 100.00 \\
\hline
\end{tabular}

Figure 2. Clustering of ten soybean cultivars by the Unweighted Pair Group Method with Arithmetic Mean (UPGMA) method for eight variables associated to seed physiological quality, stored in cold chamber (A) and under environmental conditions (B)
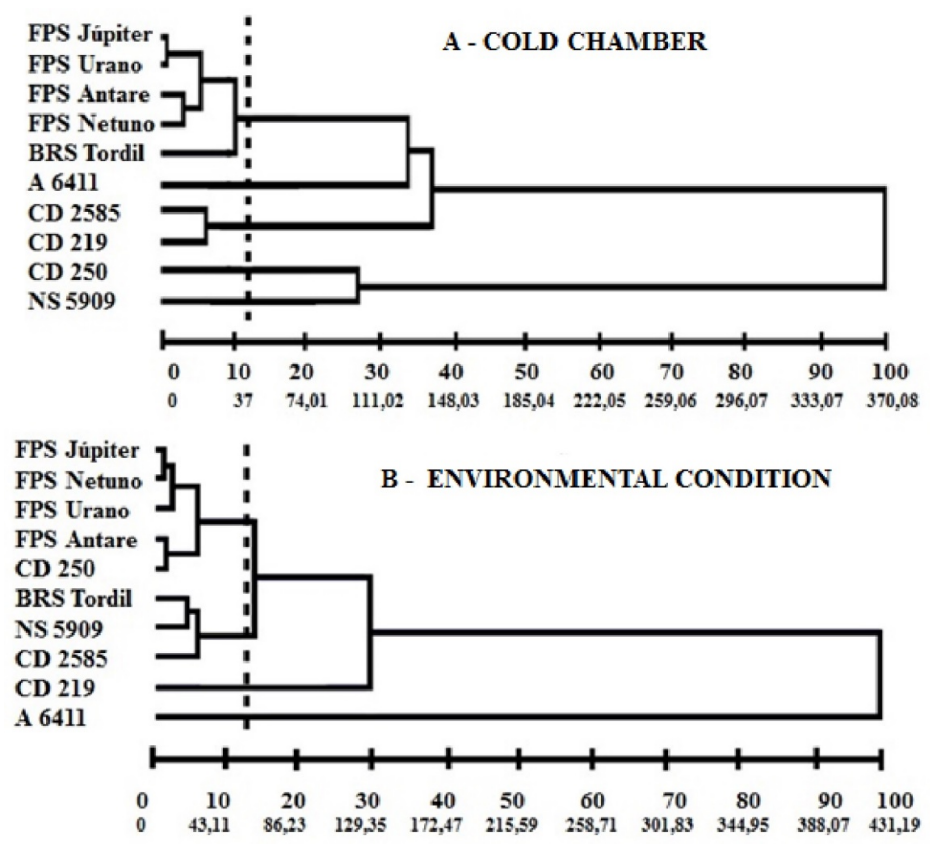
Figure 3. Two-dimensional graphical projection of the first and second canonical variable (CV 1 and CV 2) for eight variables in ten soybean cultivars stored in cold chamber (A) and under environmental conditions (B).
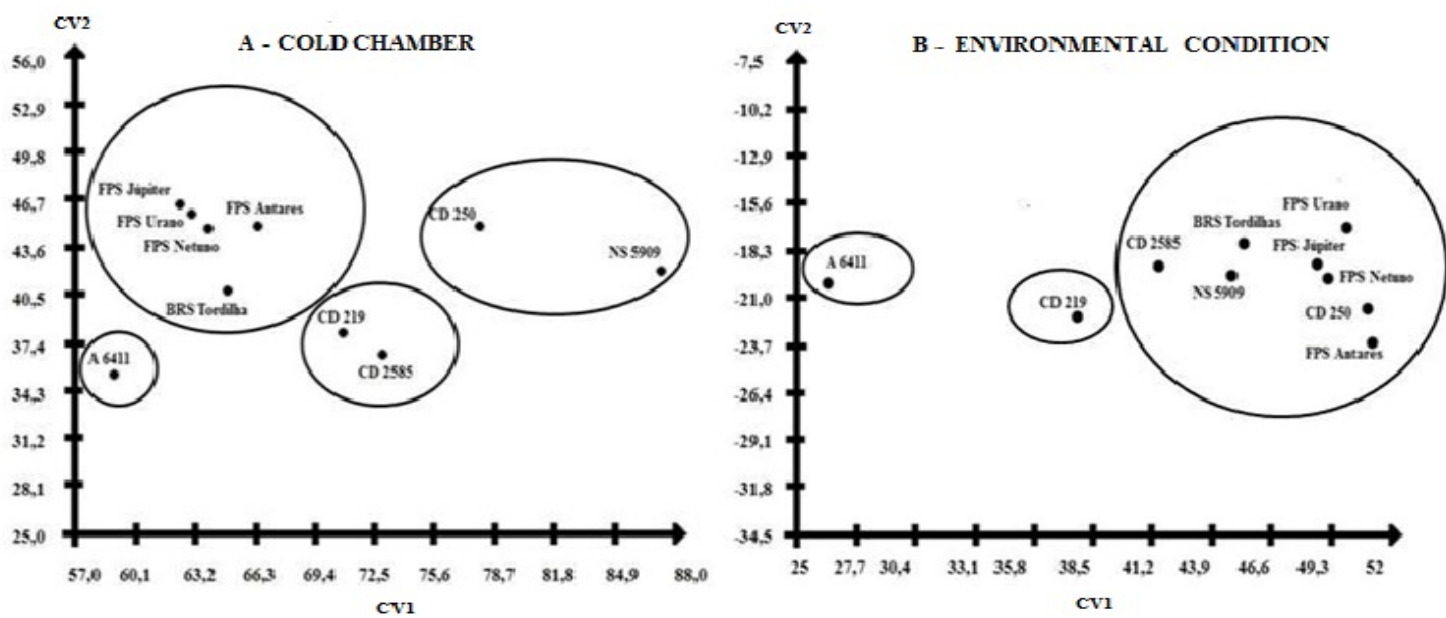

Table 5. Clustering of ten soybean cultivars by the Tocher's method for eight variables and stored in cold chamber

\begin{tabular}{cl}
\hline Groups & \multicolumn{1}{c}{ Cultivars } \\
\hline 1 & FPS Júpiter, FPS Urano, FPS Netuno, FPS Antares, BRS Tordilha \\
2 & CD 2585, CD 219 \\
3 & CD 250, NS 5909 \\
4 & A 6411 \\
\hline
\end{tabular}

The clustering pattern originated from the UPGMA and Tocher methods demonstrated similarity among FPS Júpiter, FPS Urano, FPS Antares, FPS Netuno and BRS Tordilha, regarding variables related to seed physiological quality. Furthermore, these cultivars had the highest performance in the Scott Knott's test (5\%) for all studied variables. However, CD 250 formed an isolated group by the UPGMA, underscoring its high distinctness, besides of a high seed vigor proved by the Scott Knott's test. Based on that, we can state that crosses of CD 250 with FPS Júpiter, FPS Urano, FPS Antares, FPS Netuno and BRS Tordilha could generate promising segregating populations.

Even though clustering methods and multivariate analyses are useful to identify and select contrasting genotypes, singly it does not imply hybrid superiority (SANTOS et al., 2012). Two genotypes could be quite distant genetically, i.e. the best and the worst segregates of a cross, and yet be closely related, for being members of the same population (GHADERI et al., 1984). Therefore, it is most advantageous to select two genotypes with good performance for characteristics of interest which are genetically distant from each other, since its lack of proximity would contribute to a distinct and effective genetic arrangement (CRUZ et al., 2011). Furthermore, it is important to monitor dissimilarity magnitudes and allelic complementation, for inclusion of desirable characteristics into a single cultivar (SHIMOYA et al., 2002). In this sense, Cardoso et al. (2009), studying the genetic diversity for physiological quality of papaya seeds, reported a genetic dissimilarity among genotypes through formation of seven groups by UPGMA method. Pessoa et al. (2015) applied the Tocher method in 252 pepper genotypes and found four most divergent genotypes for physiological quality of seeds, pointing these materials as promising for further segregating individuals of higher vigor. 
Although the other cultivars (A 6411, CD 2585, CD 219 and NS 5909) show low vigor to the studied variables, they are divergent and, therefore, can compose crossing blocks for heritage studies in plant breeding. So for this purpose, promising crosses among the studied cultivars would be FPS Júpiter, FPS Urano, FPS Antares, FPS Netuno and BRS Tordilha with A 6411; FPS Júpiter, FPS Urano, FPS Antares, FPS Netuno and BRS Tordilha with CD 2585; FPS Júpiter, FPS Urano, FPS Antares, FPS Netuno and BRS Tordilha with CD 219; FPS Júpiter, FPS Urano, FPS Antares, FPS Netuno and BRS Tordilha with CD 250; FPS Júpiter, FPS Urano, FPS Antares, FPS Netuno and BRS Tordilha with NS 5909; A 6411 with CD 2585; A 6411 with CD 219; A 6411 with CD 250; A 6411 with NS 5909; CD 2585 with CD 250; CD 2585 with NS 5909; CD 219 with CD 250; and CD 250 with NS 5909.

\section{Genetic diversity under environmental conditions}

The cultivars showed interactions of cultivars $\mathrm{x}$ environment $(\mathrm{CxE})$ on the variables for seeds under environmental condition storage. Nevertheless, despite significant $\mathrm{CxE}$ interactions, FPS Júpiter, FPS Urano, FPS Antares and FPS Netuno remained in the same clustering pattern as in cold storage. This is an example of simple interaction, where although there was a change in magnitude of performaces, the cultivar ranking remained unchanged for both environments. In biological terms, this phenomenon is known as homeostasis, which is the ability of an organism to adapt its physiological functions to environmental changes it was submitted (LAVORENTI; MATSUOKA, 2001). Homeostatic cultivars have constant phenotypic expression or slightly variable from one environment to another, which is drawn up by breeders as biological stability (SQUILASSI, 2003).

Measures of dissimilarity between a pair of cultivars under environmental conditions highlighted FPS Netuno and FPS Júpiter as the least dissimilar $\left(D_{i^{\prime}}^{2}=5.19\right)$. As such, chances of genetic gains are reduced by selecting these individuals for crossings. Alternatively, the highest dissimilarity was found for the pair of FPS Antares and A $6411\left(D_{i^{\prime}}^{2}=616.07\right)$, being the most divergent and promising to the obtaining of transgressive individuals, even if A 6411 had low performance on seed physiological quality.

The findings of the analysis of canonical variables (Table 4; Figure 3B) and of the UPGMA (Figure 2B) and Tocher (Table 6) methods demonstrated a distinctive clustering of the cultivars whether stored either under environmental conditions or in cold chamber. By means of the graphical distances, genetic dissimilarity could be noted among the soybean cultivars, forming three distinct groups. The cultivars A 6411 and CD 219 were the most divergent of the others, so they composed isolated groups, whereas the other ones were allocated in a larger group (Figure 3B).

Table 6. Clustering of ten soybean cultivars by the Tocher's method for eight variables and stored under environmental conditions.

\begin{tabular}{|c|c|}
\hline Groups & Cultivars \\
\hline 1 & $\begin{array}{l}\text { FPS Júpiter, FPS Urano, FPS Netuno, } \\
\text { FPS Antares, BRS Tordilha, } \\
\text { CD 2585, CD 219, CD 250, NS } 5909\end{array}$ \\
\hline 2 & A 6411 \\
\hline
\end{tabular}

UPGMA clustering distinguished cultivars in a more diversified manner than the Tocher's method. However, both were concordant allocating A 6411 singly, reinforcing its great divergence from the others, for the variables evaluated in this study. Such result was also found when the cultivar was stored in cold chamber, that is, regardless of storage location it maintains the genetic divergence from the other cultivars. For breeding purposes, A 6411 cultivar may be promising in the study of genetic parameters defining physiological quality of soybean seeds. 
Under environmental condition, crossings between CD 250 and cultivars with FPS prefix were dissuaded for being in the same group (group 1 UPGMA). Oppositely to what was in cold storage, showing thus the environment influenced on such phenotypic expression. This is likewise seen for BRS Tordilha, NS 5909 and CD 2585 (group 2 UPGMA), while in cold chamber, they showed dissimilarity. Therefore, it is possible that these cultivars have different gene expressions for each storage environment. In particular, Büttow and Bonow (2013) claimed that gene expression studies focus on the way, time and intensity in which DNA genes are expressed in response to biotic and abiotic stresses. According Leida et al. (2012), cultivars from the same species have dissimilarity in gene expression, and identification of genes differentially expressed among them can be an effective strategy in early selection of promising genotypes for improving programs. Thus, combining gene expression studies with multivariate techniques of genetic diversity may bring greater speed in identifying and selecting high-standard genotypes on physiological quality of soybean seeds.

In short, cultivars with the best averages under environmental conditions, besides being genetically divergent, show a high potential for breeding. These cultivars can be observed within UPGMA group 1 plus BRS Tordilha, which is allocated in UPGMA group 2 (Figure 2B). This way, we may refer that promising crosses would be FPS Júpiter and BRS Tordilha; FPS Netuno and BRS Tordilha; FPS Urano and BRS Tordilha; FPS Antares and BRS Tordilha; as well as CD 250 and BRS Tordilha.

In addition to phenotypic diversity, molecular markers can be used in studies of genetic diversity for seed quality to enhance effectiveness in breeding programs. Vollmann et al. (2005), in a study in Germany, found the existence of genetic diversity in camelina, by using RAPD analysis. Furthermore, molecular markers have also been applied in studies of seed quality for other crops. QTL's for seed $\mathrm{G} \%$ were detected in tobacco (AGACKA-
MOLDOCH et al., 2015), maize (HAN et al., 2014) and rice (HANG et al., 2015); and also for contents of protein and oil in soybean seeds (CSANÁDI et al., 2001; QI et al., 2011; PATHAN et al., 2013). Nonetheless, few reports are found in literature on the use of molecular markers in studies of genetic diversity for seed physiological quality in soybean. Thus, there is a lot to be exploited to elucidate the scientific knowledge in this subject. As for soybean, Han et al. (2014) reported on a study with maize that is necessary to gain more detailed understanding on molecular mechanisms, since genetics basis for seed vigor remains unknown.

The combined analysis of phenotypic traits of quality seeds, such as G\%, FC\%, GSI, LS, DMS, EC, among others, together with information from QTL analysis using molecular markers for seed physiological quality, can be useful in genetic diversity studies for selecting superior genotypes for this trait in soybean seeds.

\section{Conclusions}

Storage environment influenced clustering of soybean cultivars.

Physiological quality was higher for seeds stored in cold chamber storage compared to those under environmental conditions.

The cultivars FPS Júpiter, FPS Urano, FPS Antares, FPS Netuno and CD 250 showed high germination and vigor, being indicated as highstandard materials for breeding programs.

A 6411 and CD 219 cultivars were allocated in isolated groups, both in cold as under environmental conditionss.

Based on averages for the different variables and clustering patterns, A 6411 can be intended to studies of genetic parameters.

The cultivars FPS Júpiter, FPS Urano, FPS Antares and FPS Netuno were grouped together by Tocher, UPGMA and canonical variable methods, regardless of storage environmental conditions. 


\section{Acknowledgements}

To the National Council for Scientific and Technological Development (CNPq), to the Coordination for the Improvement of Higher Education Personnel (Capes) and to the Research Support Foundation of Minas Gerais State (FAPEMIG) by the granting of scholarships.

\section{References}

AGACKA-MOLDOCH, M.; NAGEL, M.; DOROSZEWSKA, T.; LEWIS, R. S.; BÖRNER, A. Mapping quantitative trait loci determining seed longevity in tobacco (Nicotiana tabacum L.). Euphytica, Wageningen, v. 202, n. 3, p. 479-486, 2015.

ALENCAR, E. R.; FARONI, L. R. D.; LACERDA FILHO, A. F. de; FERREIRA, L. G.; MENEGHITTI, M. R. Qualidade dos grãos de soja em função das condições de armazenamento. Engenharia na Agricultura, Viçosa, MG, v. 16, n. 2, p. 155-166, 2008.

ALVES, E. U.; PAULA, R. C.; OLIVEIRA, A. P.; BRUNO, R. L. A.; DINIZ, A. A. Germinação de sementes de Mimosa Caesalpiniaefolia Benth. em diferentes substratos e temperaturas. Revista Brasileira de Sementes, Londrina, v. 24, n. 1, p. 169-178, 2002.

AZEVEDO, M. R. de Q. A.; GOUVEA, J. P. G. de; TROVÃO, D. M. M.; QUEIROGA, V. de P. Influência das embalagens e condições de armazenamento no vigor de sementes de gergelim. Revista Brasileira de Engenharia Agrícola e Ambiental, Campina Grande, v. 7, n. 3, p. 519-524, 2003.

BLACK, M.; BEWLEY, J. D.; HALMER, P. The encyclopedia of seeds: science, technology and uses. Cambridge: CABI, 2006. 828 p.

BRASIL. Ministério da Agricultura, Pecuária e Abastecimento. Regras para análise de sementes. Secretaria de Defesa Agropecuária. Brasília: Mapa/ACS, 2009. $399 \mathrm{p}$.

BÜTTOW, M. V.; BONOW, S. Estudos de expressão gênica e possibilidades de aplicação no melhoramento genético de pessegueiro [Prunus persica (L.) Batsch]. Pelotas: Embrapa Clima Temperado, 2013. 27 p. (Documentos, 370).

CARDOSO, D. L.; SILVA, R. F. da; PEREIRA, M. G.; VIANA, A. P.; ARAÚJO, E. F. Diversidade genética e parâmetros genéticos relacionados à qualidade fisiológica de sementes em germoplasma de mamoeiro. Revista Ceres, Viçosa, MG, v. 56, n. 5, p. 572-579, 2009.
CARVALHO, E. R.; MAVAIEIE, D. P. da R.; OLIVEIRA, J. A.; CARVALHO, M. V. de; VIEIRA, A. R. Alterações isoenzimáticas em sementes de cultivares de soja em diferentes condições de armazenamento. Pesquisa Agropecuária Brasileira, Brasília, v. 49, n. 12, p. 967976, 2014.

CARVALHO, N. M. de; NAKAGAWA, J. Sementes: ciência, tecnologia e produção. 4. ed. Jaboticabal: Funep, 2000. $588 \mathrm{p}$.

Sementes: ciência, tecnologia e produção. 5. ed. Jaboticabal: FUNEP, 2012. 590 p.

CRUZ, C. D. Genes: a software package for analysis in experimental statistics and quantitative genetics. Acta Scientiarum, Maringá, v. 35, n. 3, p. 271-276, 2013.

CRUZ, C. D.; FERREIRA, F. M.; PESSONI, L. A. Biometria aplicada ao estudo da diversidade genética. Visconde do Rio Branco: Suprema, 2011. 620 p.

CSANÁDI, G.; VOLLMANN, J.; STIFT, G.; LELLEY, T. Seed quality QTLs identified in a molecular map of early maturing soybean. Theoretical and Applied Genetics, Berlin, v. 103, n. 6, p. 912-919, 2001.

DELOUCHE, J. C.; BASKIN, C. C. Accelerated aging techniques for predicting the relative storability of seed lots. Seed Science and Technology, Zurich, v. 1, n. 2, p. 427-452, 1973.

FALCONER, D. S. Introdução à genética quantitativa. Viçosa, MG: UFV, 1981. 279 p.

FRANZIN, S. M.; MENEZES, N. L. de; GARCIA, D. C.; WRASSE, C. F. Métodos para avaliação do potencial fisiológico de sementes de alface. Revista Brasileira de Sementes, Londrina, v. 26, n. 2, p. 63-69, 2004.

GHADERI, A.; ADAMS, M. W.; NASSIB, A. M. Relationship between genetic distance and heterosis for yield and morphological traits in dry edible bean and fava bean. Crop Science, Madison, v. 14, n. 1, p. 24-27, 1984.

GOLDFARB, M.; QUEIROGA, V. de P. Considerações sobre o armazenamento de sementes. Tecnologia $e$ Ciência Agropecuária, João Pessoa, v. 7, n. 3, p. 71-74, 2013.

HAN, Z.; KU, L.; ZHANG, Z.; ZHANG, J.; GUO, S.; LIU, H.; ZHAO, R.; REN, Z.; ZHANG, L.; SU, H.; DONG, L.; CHEN, Y. QTLs for seed vigor-related traits identified in maize seeds germinated under artificial aging conditions. Plos One, San Francisco, v. 9, n. 3, p. 1-13, 2014.

HANG, N. T.; LIN, Q.; LIU, L.; LIU, X.; LIU, S.; WANG, W.; LI, L.; HE, N.; LIU, Z.; JIANG, L.; WAN, J. Mapping QTLs related to rice seed storability under natural and artificial aging storage conditions. Euphytica, Wageningen, v. 203, n. 3, p. 673-681, 2015. 
HÖFS, A.; SCHUCH, L. O. B.; PESKE, S. T.; BARROS, A. C. S. A. Emergência e crescimento de plântulas de arroz em resposta à qualidade fisiológica de sementes. Revista Brasileira de Sementes, Londrina, v. 26, n. 1, p. 92-97, 2004.

KRZYZANOWSKI, F. C.; FRANÇA NETO, J. B. Vigor de sementes: conceitos e testes. Londrina: ABRATES, 1999. $218 \mathrm{p}$.

LAVORENTI, N. A.; MATSUOKA, S. Combinação de métodos paramétricos e não paramétricos na análise de estabilidade de cultivares de cana-de-açúcar. Pesquisa Agropecuária Brasileira, Brasília, v. 36, n. 4, p. 653-658, 2001.

LEIDA, C.; ROMEU, J. F.; GARCÍA-BRUNTON, J.; RÍOS, G.; BADANES, M. L. Gene expression analysis of chilling requirements for flower bud break in peach. Plant Breeding, Malden, v. 131, n. 2, p. 329-334, 2012.

MAGUIRE, J. D. Speed of germination-aid in selection and evaluation for seedlig emergence and vigor. Crop Science, Madison, v. 2, n. 1, p. 176-177, 1962.

MARCOS FILHO, J. Fisiologia de sementes de plantas cultivadas. Piracicaba: FEALQ, 2005. 495 p.

MARCOS FILHO, J. Pesquisa sobre vigor de sementes de hortaliças. Informativo ABRATES, Londrina, v. 11, n. 3, p. 63-75, 2001.

MARTINS, C. C.; UNÊDA-TREVISOLI, S. H.; MÔRO, G. V.; VIEIRA, R. D. Metodologia para seleção de linhagens de soja visando germinação, vigor e emergência em campo. Revista Ciência Agronômica, Fortaleza, v. 47, n. 3, p. 455-461, 2016.

MENGARDA, L. H. G.; LOPES, J. C.; ZANOTTI, R. F.; ALEXANDRE, R. S. Diversity analysis of papaya (Carica papaya L.) genotypes related to seed quality. Australian Journal of Crop Science, Brisbane, v. 9, n. 3, p. 223-231, 2015. Disponível em: <http://www.cropj. com/lopes_9_3_2015_223_231.pdf $>$. Acesso em: 17 ago. 2015.

NERLING, D.; COELHO, C. M. M.; NODARI, R. O. Genetic diversity for physiological quality of seeds from corn (Zea mays L.) intervarietal crossbreeds. Journal of Seed Science, Londrina, v. 35, n. 4, p. 449-456, 2013.

PATHAN, S. M.; VUONG, T.; CLARK, K.; LEE, J-D.; SHANNON, J. G.; ROBERTS, C. A.; ELLERSIECK, M. R.; BURTON, J. W.; CREGAN, P. B.; HYTEN, D. L.; NGUYEN, H. T.; SLEPER, D. A. Genetic mapping and confirmation of quantitative trait loci for seed protein and oil contents and seed weight in soybean. Crop Science, Madison, v. 53, n. 3, p. 765-774, 2013.
PESSOA, A. M. S.; BARROSO, P. A.; RÊGO, E. R. do; MEDEIROS, G. D. A.; BRUNO, R. L. A.; RÊGO, M. M. do. Genetic divergence of physiological quality traits of seeds in a population of peppers. Genetics and Molecular Research, Ribeirão Preto, v. 14, n. 4, p. 12479-12488, 2015.

QI, Z.; WU, Q.; HAN, X.; SUN, Y.; DU, X.; LIU, C.; JIANG, H.; HU, G.; CHEN, Q. Soybean oil content QTL mapping and integrating with meta-analysis method for mining genes. Euphytica, Wageningen, v. 179, n. 3, p. 499-514, 2011.

RIGON, J. P. G.; CAPUANI, S.; BRITO NETO, J. F.; ROSA, G. M.; WASTOWSKI, A. D.; RIGON, C. A. G. Dissimilaridade genética e análise de trilha de cultivares de soja avaliada por meio de descritores quantitativos. Revista Ceres, Viçosa, MG, v. 59, n. 2, p. 233-240, 2012.

ROBERTS, E. H. Storage environment and control of viability. In: ROBERTS, E. H. (Ed.). Viability of seeds. London: Chapman and Hall Limited, 1972. p. 14-18.

SANTOS, E. R. dos; BARROS, H. B.; CAPONE, A.; MELO, A. V. de; CELLA, A. J. da S.; SANTOS, W. R. dos. Divergência genética entre genótipos de soja com base na qualidade de sementes. Revista Brasileira de Ciências Agrárias, Recife, v. 7, n. 2, p. 247-254, 2012.

SHIMOYA, A.; CRUZ, C. D.; FERREIRA, R. de P.; PEREIRA, A. V.; CARNEIRO, P. C. S. Divergência genética entre acessos de um banco de germoplasma de capim-elefante. Pesquisa Agropecuária Brasileira, Brasília, v. 37, n. 7, p. 971-980, 2002.

SILVA, J. S. Secagem e armazenagem de produtos agrícolas. Viçosa, MG: Aprenda Fácil, 2008. 560 p.

SMANIOTTO, T. A. de S.; RESENDE, O.; MARÇAL, K. A. F.; OLIVEIRA, D. E. C. de; SIMON, G. A. Qualidade fisiológica de sementes de soja armazenadas em diferentes condições. Revista Brasileira de Engenharia Agricola e Ambiental. Campina Grande, v. 18, n. 4, p. 446-453, 2014.

SQUILASSI, M. G. Interação de genótipos com ambientes. Aracaju: Embrapa Tabuleiros Costeiros, 2003. 47 p. Disponível em: < http//www.cpatc.embrapa. br>. Acesso em: 7 jun. 2016.

ULLMANN, R.; RESENDE, O.; CHAVES, T. H.; OLIVEIRA, D. E. C. de O.; COSTA, L. M. Qualidade fisiológica das sementes de sorgo sacarino submetidas à secagem em diferentes condições de ar. Revista Brasileira de Engenharia Agrícola e Ambiental, Campina Grande, v. 19, n. 1, p. 64-69, 2015. 
UNIVERSIDADE FEDERAL DE VIÇOSA - UFV. Departamento de Engenharia Agrícola. Estação Climatológica Principal de Viçosa. Boletimmeteorológico 2013 e 2014. Viçosa, MG, 2016. Disponível em: <http:// www.posmet.ufv.br/?page id=1253>. Acesso em: 13 maio 2016.

VANZOLINI, S.; ARAKI, C. A. dos S.; SILVA, A. C. T. M. da; NAKAGAWA, J. Teste de comprimento de plântula na avaliação da qualidade fisiológica de sementes de soja. Revista Brasileira de Sementes, Londrina, v. 29, n. 2, p. 90-96, 2007.

VASCONCELOS, E. S. de; REIS, M. S.; SEDIYAMA, T.; CRUZ, C. D. Qualidade fisiológica de sementes de cultivares e linhagens de soja no Estado de Minas Gerais. Acta Scientiarum Agronomy, Maringá, v. 31, n. 2, p. $307-$ 312, 2009.

VIEIRA, R. D.; PENARIOL, A. L.; PERECIN, D.; PANOBIANCO, M. Condutividade elétrica e teor de água inicial das sementes de soja. Pesquisa Agropecuária Brasileira, Brasília, v. 37, n. 9, p. 1333-1338, 2002.
VILLELA, O. T. Diversidade fenotípica e molecular de cultivares brasileiras de soja portadoras de gene RR. 2013. Dissertação (Mestrado em Agronomia) - Faculdade de Ciências Agrárias e Veterinárias, Universidade Estadual Paulista, Jaboticabal.

VOLLMANN, J.; GRAUSGRUBER, H.; STIFT, G.; DRYZHYRUK, V.; LELLEY, T. Genetic diversity in camelina germplasm as revealed by seed quality characteristics and RAPD polymorphism. Plant Breeding, Berlim, v. 124, n. 5, p. 446-453, 2005.

ZUCARELI, C.; BRZEZINSKI, C. R.; ABATI, J.; WERNER, F.; RAMOS JÚNIOR, E. U.; NAKAGAWA, J. Qualidade fisiológica de sementes de feijão carioca armazenadas em diferentes ambientes. Revista Brasileira de Engenharia Agrícola e Ambiental, Campina Grande, v. 19, n. 8, p. 803-809, 2015. 